\title{
The Role of Stress Metabolites in Establishing Host-parasite Specificity between Sweet Potato and Ceratocystis fimbriata, Black Rot Fungus
}

\author{
Kumiko Yasuda and Mineo KoJima \\ Institute for Biochemical Regulation, Faculty of Agriculture, \\ Nagoya University, Chikusa, Nagoya 464, Japan \\ Received January 16, 1986
}

\begin{abstract}
Differential growth of two strains of Ceratocystis fimbriata EII. and Halst. was demonstrated in liquid media containing exudates from the infected sweet potato root tissues; the germ tube growth of the taro strain, incompatible with sweet potato, was specifically inhibited in medium containing the exudate from the taro-strain-infected tissues which had been incubated for $18 \mathrm{hr}$, whereas germ tube growth of the sweet potato strain, compatible with sweet potato, was not inhibited in media containing the same dilution of any exudates. Furanoterpenoid phytoalexins and umbelliferone were shown to be the main cause of differential inhibitory activity of exudates from the infected tissues. The taro strain was more sensitive than the sweet potato strain to inhibition by furanoterpenoid phytoalexins in both germination and germ tube growth. Umbelliferone inhibited germ tube growth of the taro strain only but not the seet potato strain, at the concentrations tested.

The content of umbelliferone increased before that of furanoterpenoid phytoalexins in both tissues infected by the sweet potato and taro strains. Umbelliferone accumulated to the same extent in the early stages in both tissues. On the other hand, the content of furanoterpenoid phytoalexins in the tissues infected by the taro strain started to increase earlier (12 hr) than that in the tissues infected by the sweet potato strains $(18 \mathrm{hr})$.
\end{abstract}

Various strains of Ceratocystis fimbriata EII. and Halst. were isolated from black rot lesions on sweet potato, coffee, prune, cacao, oak, taro, and almond plants. These strains show host specificity. For example, the sweet potato strain can cause symptoms on sweet potato but not taro, whereas the taro strain can cause symptoms on taro but not sweet potato.

Host-parasite specificity has been demonstrated and studied extensively in many systems in recent years. Those studies have shown some specificity determinative factors such as host specific toxins, ${ }^{1 \sim 4)}$ a specific elicitor, ${ }^{5)}$ a secific blocker, ${ }^{6)}$ and a spore agglutination factor or lectin. ${ }^{711}$ At present, however, none of these factors seems to universally account for specificity. On the other hand, there is one feature common to most hostparasite specific systems; the compatible interaction allows the growth of the parasite on the host, whereas the incompatible interaction results in cessation of growth of the parasite. However, specific mechanisms might vary considerably among systems.

In this paper, we attempted to find the factor(s) in the exudate of infected sweet potato root which is directly involved in differential growth behavior of the sweet potato and taro strains on the tissues. we isolated and identified furanoterpenoid phytoalexins and umbelliferone as possible causal factors and studied their toxicity on the two strains of $C$. fimbriata as well as their accumulation in the infected sweet potato roots.

\section{MATERIALS AND METHODS}

Plant materials. Sweet potato roots (Ipomea batatas Lam, cv. Norin 1) were harvested in October and stored at $13^{\circ} \mathrm{C}$ until used. The outer cortical tissues of roots were removed and the inner root tissues were used for experiments. 
Preparation of endoconidial spore suspension. Endoconidial spore suspensions of the sweet potato and taro strains of $C$. fimbriata were prepared by the method reported earlier. ${ }^{12)}$

Preparation of fresh tissue extract. The fresh tissue extract was prepared by our previous method. ${ }^{12)}$

Preparation of sweet potato root tissue exudates. Root tissue disks $(1.5 \times 0.5 \mathrm{~cm})$ were inoculated with spore suspensions of either the sweet potato or taro strain $(1 \times$ $10^{5} /$ disk) and incubated at $25^{\circ} \mathrm{C}$. After $18 \mathrm{hr}$ of incubation, the inoculated surfaces of disks were immersed in water $(2 \mathrm{ml} / \mathrm{disk})$ and shaken at $4^{\circ} \mathrm{C}$ for $3 \mathrm{hr}$. The disks were then removed and the water solutions were centrifuged at $2,300 \times g$ for $5 \mathrm{~min}$. The supernatants were filtered through a membrane with an exclusion limit of $10 \mathrm{kD}$ (YM-10, Amicon Corporation). The filtrates were used as tissue exudates. Tissue exudates were also prepared from fresh disks or disks incubated for $18 \mathrm{hr}$ without inoculation by the same method.

Growth of spores in liquid media containing tissue exudates. Spores $\left(1 \times 10^{6}\right)$ of the sweet potato and taro strains were incubated in $1.2 \mathrm{ml}$ of liquid media containing $1 \mathrm{ml}$ of exudate, $0.1 \mathrm{ml}$ of $0.2 \mathrm{M} \mathrm{MES}-\mathrm{NaOH}(\mathrm{pH} 6.5)$ and $0.1 \mathrm{ml}$ of ${ }^{x}$ fresh tissue extract as a nutrient source, at $25^{\circ} \mathrm{C}$ on a shaker at 100 strokes/min. After $3.5 \mathrm{hr}$ of incubation, the growth of spores was examined with a light microscope and photographs were taken. The germ tube lengths of more than 200 germinated spores, on photographs, were measured with a curvimeter. The difference in germ tube length was tested for significance using Kruskal-Wallis's test. Spore germination in all media ranged from 85 to $90 \%$.

Identification of inhibitory compounds in infected tissue exudate. The filtered exudate from the taro-strain-infected tissues was freeze dried. The dried powder was taken up in a small volume of water and centrifuged to remove insoluble material. The supernatant was extracted six times with an equal volume of diethyl ether. Inhibitory activity of the water and the diethyl ether layers was assayed using taro strain spores after complete removal of organic solvent by evaporation in vacuo. Inhibitory activity was detected only in the diethyl ether layer fraction.

The diethyl ether layer fraction was analyzed by silica gel TLC with $n$-hexane-ethylacetate $(3: 2, \mathrm{v} / \mathrm{v})$. The separated components were detected by short UV light, Ehrlich's reagent, or sulfuric acid. In addition, a plate after development was sprayed with the taro strain spore suspension $\left(1.9 \times 10^{7} / \mathrm{ml}\right)$ in $50 \mathrm{~mm}$ MES- $\mathrm{NaOH}(\mathrm{pH} 6.5)$ containing fresh tissue extract $(25 \%)$ as nutrient source, and incubated at $25^{\circ} \mathrm{C}$ in a moist chamber to detect the inhibitory compound(s) on the plate. White spots, indicating inhibited growth of the fungi, emerged against a dark background of the plate after incubation for 3 days. These
TLC plates revealed the occurrence of furanoterpenoid phytoalexins and a fluorescent compound at $R f 0.32$ as the major inhibitory compounds in the exudate.

The fluorescent compound at $R f 0.32$ was identified as umbelliferone by HPLC (column: Develosil ODS 5, eluting solvent: $25 \%$ methanol with $10 \mathrm{~mm}$ acetic acid), silica gel TLC using three solvent systems; ethanol-ethylacetate $(1: 9, \mathrm{v} / \mathrm{v}, R f=0.72)$, toluene: acetone $(1: 1, \mathrm{v} / \mathrm{v}, R f=0.68)$, $n$-butanol-pyridine-water $(14: 3: 3, \mathrm{v} / \mathrm{v}, R f=0.84)$, and cellulose TLC ( $5 \%$ acetic acid, $R f=0.48)$. Some other faint fluorescent spots were also detected on the plate, which were assumed to be coumarins such as scopoletin and esculetin. These compounds, however, were ignored, as they did not show clear inhibitory spots on the bioautogram, and only occur in trace amounts in the infected tissues. ${ }^{17)}$

Isolation of furanoterpenoid phytoalexins and umbelliferone from infected tissue exudate. The lyophilized exudate from the taro-strain-infected tissues was dissolved in $60 \%$ ethanol solution and centrifuged to remove insoluble material. The supernatant was taken to dryness and dissolved in a small volume of methanol solution, which formed insoluble material. The insoluble material was removed by centrifugation. The suparnatant was evaporated to dryness and dissolved in diethyl ether. The diethyl ether solution was then repeatedly extracted with $0.2 \%(\mathrm{v} / \mathrm{v})$ ammonia in water until the aqueous ammonia layer showed no UV-fluorescence. Analysis by silica gel TLC indicated that partially degraded products of umbelliferone and other minor fluorescent compounds preferentially partitioned in the ammonia water layer, whereas all intact furanoterpenoid phytoalexins partitioned in the diethyl ether layer. Therefore, the toxicity of furanoterpenoid phytoalexins was assayed using samples prepared as above, while the toxicity of umbelliferone was assayed using an authentic sample.

Growth of spores in liquid media containing varied concentrations of furanoterpenoid phytoalexins or umbelliferone. Spores $\left(0.5 \times 10^{5}\right)$ of the sweet potato or taro strain were incubated in $0.5 \mathrm{ml}$ of liquid medium containing $50 \mu \mathrm{l}$ of the fresh tissue extract as a nutrient source and varied amounts of furanoterpenoid phytoalexins or umbelliferone at $25^{\circ} \mathrm{C}$ on a shaker at 100 strokes $/ \mathrm{min}$. After $3.5 \mathrm{hr}$ of incubation, the suspensions were examined with a light microscope and photographed. The germination percentage was determined by counting about 150 spores at each examination. The germ tube length of spores, exclusive of ungerminated spores, was measured and analyzed statistically as described above.

Measurement of furanoterpenoid phytoalexins and umbelliferone contents in infected disks. Disks $(1.5 \times 0.3 \mathrm{~cm})$ were inoculated with spore suspensions $\left(1.0 \times 10^{7}\right.$ spores/ $\mathrm{ml})$ of either the sweet potato or taro strain $(20 \mu \mathrm{l} / \mathrm{disk})$ and incubated at $25^{\circ} \mathrm{C}$. After incubation for various pe- 
riods, 12 disks (about $10 \mathrm{~g}$ ) were harvested for each measurement of furanoterpenoid phytoalexins and umbelliferone.

Furanoterpenoid phytoalexins were extracted and measured by the methods of Hyodo et al. ${ }^{13)}$

Umbelliferone was extracted and assayed by the modified method of Minamikawa et al. ${ }^{14)}$ Twelve disks were homogenized in $10 \mathrm{ml}$ of methanol and refluxed for $30 \mathrm{~min}$. The homogenate was filtered through a glass filter. The filtrate was condensed to dryness by evaporation and dissolved in $4 \mathrm{ml}$ of methanol. The methanol solution was mixed with $40 \mathrm{ml}$ of diethyl ether and kept on ice for $30 \mathrm{~min}$. The insoluble material formed was removed by centrifugation at $2,300 \times g$ for $5 \mathrm{~min}$. The supernatant was condensed, spotted onto a silica gel TLC plate, and developed with $n$-hexane-ethylacetate-acetic acid (49: $49: 2, \mathrm{v} / \mathrm{v})$. The spot of umbelliferone at $R f 0.52$ was scraped off and eluted with hot methanol. The methanol solution was condensed to dryness and dissolved in $5 \mathrm{ml}$ of a mixture of $0.2 \mathrm{~N} \mathrm{NaHCO}_{3}$ and ethanol $(1: 1, \mathrm{v} / \mathrm{v})$. The umbelliferone in the solution was measured by the intensity of fluorescence using authentic umbelliferone as a standard.

\section{RESULTS}

Differential growth of spores of sweet potato and taro strains in liquid media containing infected tissue exudates

The dense black mycelial mats developed on sweet potato root tissues incubated for 3 days after inoculation with the sweet potato strain, whereas no mycelial growth was observed by eye on the taro-strain-inoculated tissues. In order to obtain information about the compound(s) which may be responsible for differential growth of the sweet potato and taro strains on the infected tissues, we prepared exudates from the infected tissue, the incubated tissue without inoculation as well as fresh tissue. The various tissue exudates were tested for spore growth of the two strains (Table I). None of the various tissue exudates caused any inhibition of germ tube growth of spores of the sweet potato strain at the dilution tested. In contrast, the same dilution of the exudate from the taro-strain-infected tissues significantly inhibited germ tube growth of the taro strain, whereas the other exudates did not. Germination of both strains ranged from 85 to $90 \%$ in all media tested.

When the growth inhibition by the exudates
TAble I. Growth of $C$. fimbriata In LiQuid Medium CONTAINING ExudATES From INFECTED SWEet Potato Root Tissues

Experimental conditions are described in the text.

\begin{tabular}{lcc}
\hline & \multicolumn{2}{c}{$\begin{array}{c}\text { Mean germ tube length } \\
(\mu \mathrm{m})\end{array}$} \\
\cline { 2 - 3 } Addition to medium & $\begin{array}{c}\text { Sweet potato } \\
\text { strain }\end{array}$ & $\begin{array}{c}\text { Taro } \\
\text { strain }\end{array}$ \\
\cline { 2 - 3 } & 76.8 & 66.8 \\
& 82.6 & 67.0 \\
None (control) & 71.8 & 78.0 \\
$\begin{array}{l}\text { Exudate from fresh tissue } \\
\text { Exudate from incubated } \\
\text { tissues without } \\
\quad \text { inoculation }\end{array}$ & & \\
$\begin{array}{l}\text { Exudate from sweet } \\
\text { potato strain-infected } \\
\text { tissues }\end{array}$ & 73.0 & 61.4 \\
$\begin{array}{l}\text { Exudate from taro strain- } \\
\text { infected tissues }\end{array}$ & 69.0 & $39.8^{a}$ \\
\hline
\end{tabular}

a Germ tube length significantly shorter than control $(p<0.001)$.

was assayed after condensation, not only the exudate from the taro-strain-infected tissues but also the exudate from the sweet potatostrain-infected and the uninfected tissues inhibited germ tube growth of both strains. From these results we assumed that the taro-straininfected tissues had produced a larger amount of certain compound(s) with differential toxicity than other tissues after $18 \mathrm{hr}$ of inoculation.

Identification of inhibitory compound(s) in infected tissue exudate

We tried to identify the inhibitory compound(s) in the infected sweet potato roots using the exudate from the taro-strain-infected tissues. The inhibitory activity of the exudate was heat stable and was recovered in the filtrate through a membrane with an exclusion limit of $10 \mathrm{kd}$. Inhibitory compound(s) in the exudate was isolated and identified by the procedures described under MATERIALS AND Methods. When the water solution of the condensed exudate was extracted with diethyl ether, the inhibitory activity was distributed exclusively in the diethyl ether layer. This fraction was then chromatographed on silica 
gel plates with $n$-hexane-ethylacetate $(3: 2$, $\mathrm{v} / \mathrm{v})$. Inspection of the plate under short UV light revealed a highly fluorescent spot at $R f$ 0.32 and a few faint fluorescent spots. Spraying the plate with Ehrlich's reagent developed spots of furanoterpenoid phytoalexins with characteristic color such as ipomeamarone, dehydroipomeamarone, ipomeamaronol, and 9-hydroxyfarnesol. ${ }^{15)}$ No additional spots were detected by spraying with sulfuric acid, which detected all non-volatile organic compounds (data not shown). Furthermore, the $R f$ values of the inhibitory spots detected on the bioautogram using the taro strain spores coincided with those of either the fluorescent compound at $R f 0.32$ or furanoterpenoid phytoalexins (data not shown). These results indicated that the inhibitory activity of the exudate from the taro-strain-infected tissues could be attributed mainly to the fluorescent compound at $R f 0.32$ and several furanoterpenoid phytoalexins. The fluorescent compound at $R f 0.32$ was identified as umbelliferone by HPLC and TLC using four solvent systems (MATERIALS AND Methods).

Effects of furanoterpenoid phytoalexins and umbelliferone on germination and germ tube growth

Germination and germ tube growth of spores of the sweet potato and taro strains were examined in media containing varied concentrations of furanoterpenoid phytoalexins isolated from the exudate of the tarostrain-infected tissues (Fig. 1) or authentic umbelliferone (Fig. 2). The taro strain was more sensitive to furanoterpenoid phytoalexins in both germination and germ tube growth than the sweet potato strain.

Umbelliferone caused little inhibition of germination of both the sweet potato and taro strains up to a concentration as high as $150 \mu \mathrm{g} / \mathrm{ml}$, but it inhibited germ tube growth differentially; a lower concentration $(72 \mu \mathrm{g} /$ $\mathrm{ml}$ ) of umbelliferone considerably inhibited the germ tube growth of the taro strain, while the germ tube growth of the sweet potato strain was not affected significantly by umbelliferone at a concentration of $150 \mu \mathrm{g} / \mathrm{ml}$.

\section{Changes in furanoterpenoid phytoalexins and} umbelliferone contents in infected tissues

The amounts of furanoterpenoid phytoalexins increased differently in tissues infected by the sweet potato and taro strains (Fig. 3). Furanoterpenoid phytoalexins in the taro-strain-infected tissues began to increase $12 \mathrm{hr}$ after inoculation and reached a plateau in $24 \mathrm{hr}$. In contrast, furanoterpenoid phytoalexins contents started to increase at $18 \mathrm{hr}$

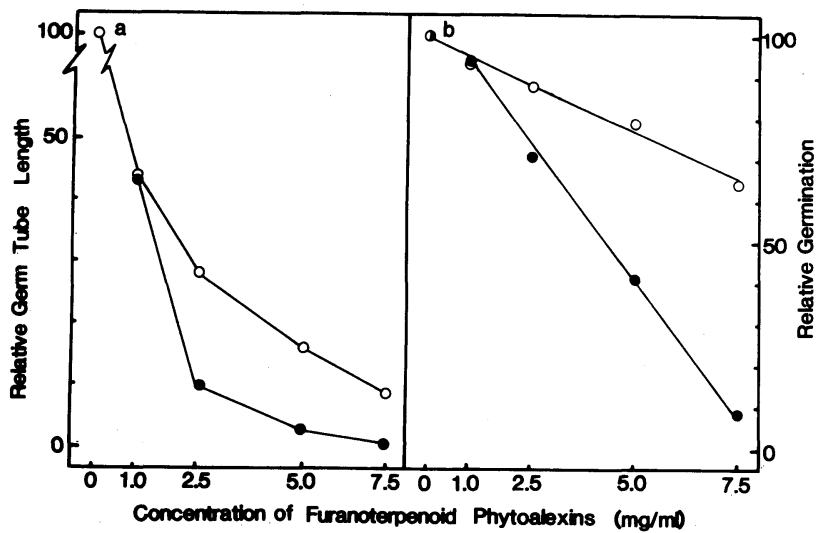

FIG. 1. Effects of Furanoterpenoid Phytoalexins on Growth of the Sweet Potato $(\bigcirc-\bigcirc)$ and the Taro (-) Strains of C. fimbriata in Liquid Media.

(a) germ tube growth; (b) germination. Experimental conditions are described in the text. The germ tube growth and germination are presented as values relative to those in medium without furanoterpenoid phytoalexins. Germ tube length (a) of the two strains at $2.5,5.0$, and $7.5 \mathrm{mg} / \mathrm{ml}$ of furanoterpenoid phytoalexins differ significantly $(p<0.001)$. 


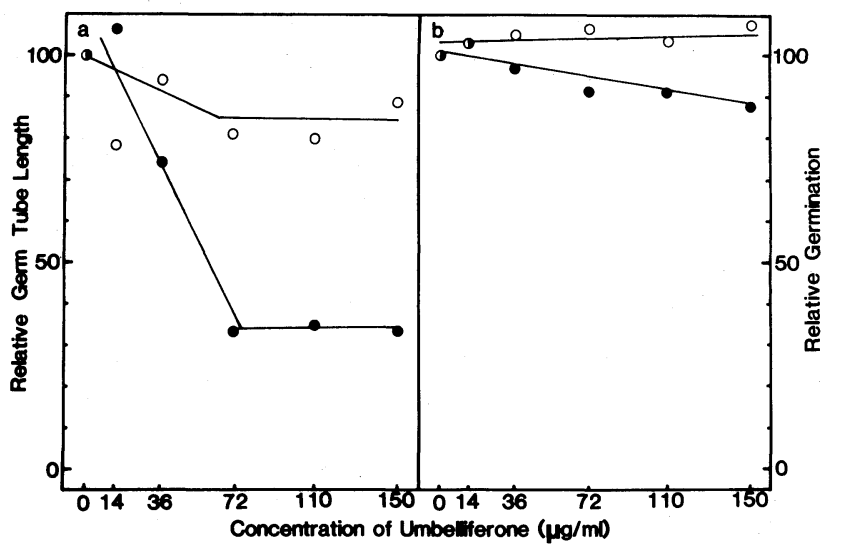

FIG. 2. Effects of Umbelliferone on Growth of the Sweet Potato $\left(\mathrm{O}_{-} \mathrm{O}\right)$ and Taro $(-)$ Strains of $C$. fimbriata in the Liquid Media.

(a) germ tube length; (b) germination. Experimental conditions are described in the text. The germ tube growth and germination are presented as values relative to those in medium without umbelliferone. Germ tube length of the two strains at $18,36,55$, and $75 \mu \mathrm{g} / \mathrm{ml}$ of umbelliferone differs significantly $(p<0.001)$.

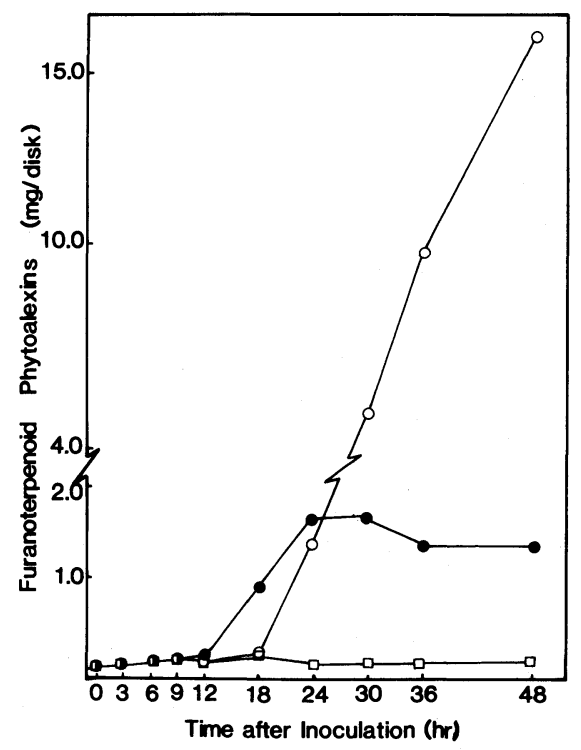

FIG. 3. Changes in Contents of Furanoterpenoid Phytoalexins in the Infected Sweet Potato Root Disks during Incubation at $25^{\circ} \mathrm{C}$.

Inoculated by the sweet potato strain spores $(\bigcirc-\bigcirc)$, taro strain spores $(--)$ ), or without inoculation $(\square-\square)$. Experimental conditions are described in the text.

in the sweet potato-strain-infected tissues, $6 \mathrm{hr}$ later than in the tissues infected by the taro strain, and continued to increase up to the end of the incubation period. No furanoterpenoid phytoalexins accumulated in the uninfected

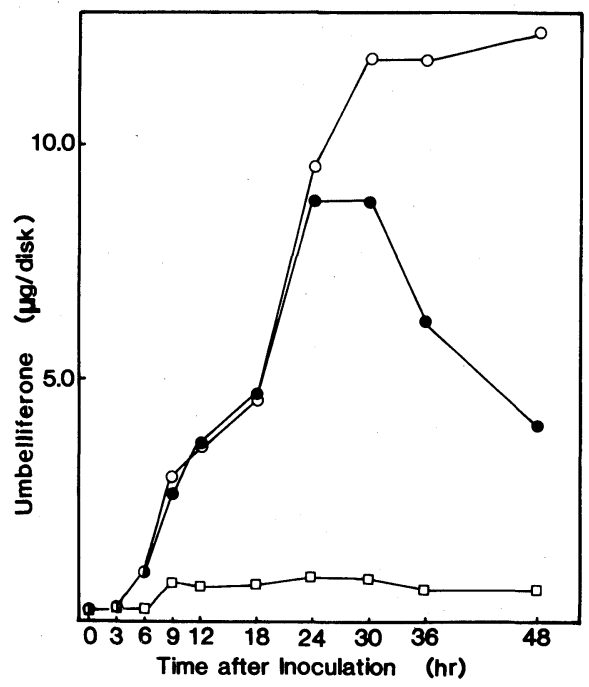

FIG. 4. Changes in Content of Umbelliferone in Infected Sweet Potato Root Disks Incubated at $25^{\circ} \mathrm{C}$.

Inoculated by the sweet potato strain spores $(\bigcirc-\bigcirc)$, taro strain spores $(--)$ ), or without inoculation $(\square-\square)$. Experimental conditions are described in the text.

\section{tissues.}

Umbelliferone began to increase $3 \mathrm{hr}$ after inoculation and continued to increase until $24 \mathrm{hr}$ in tissues infected either with the sweet potato or taro strains (Fig. 4), then it decreased in the taro-strain-infected tissues, while that in the sweet potato-strain-infected tissues continued to increase at a slower rate 
(Fig. 4). Only a little umbelliferone accumulated in the uninfected tissues.

\section{DISCUSSION}

Differential growth of the sweet potato and taro strains of $C$. fimbriata was observed in liquid media containing exudates from infected sweet potato root tissues; growth of the taro strain was specifically inhibited in the medium containing exudate from tissues incubated for $18 \mathrm{hr}$ after inoculation with the taro strain (Table I). We isolated and identified furanoterpenoid phytoalexins and umbelliferone as the main causes of inhibition.

It has been already shown that furanoterpenoid phytoalexins composed of many components such as ipomeamarone, ${ }^{16,17)}$ ipomeamaronol, ${ }^{18,19)}$ and dehydroipomeamarone, ${ }^{20)}$ and coumarins such as umbelliferone and scopoletin $^{21)}$ are produced in sweet potato root tissues infected by $C$. fimbriata. In addition, Uritani and co-workers demonstrated the toxicity of these stress metabolites toward the fungus and studied their production in sweet potato root tissues in the later stages of infection by the sweet potato strain. ${ }^{12,14)}$

In this study, we tried to elucidate the role of these stress metabolites in the early stages of infection, especially in establishing hostparasite specificity. Firstly, we compared the toxicity of furanoterpenoid phytoalxins from the sweet potato root tissues in the early stage of infection by taro strain and umbelliferone toward the sweet potato and taro strains (Figs. 1 and 2). Inhibitory activity of furanoterpenoid phytoalexins was not confined to a single component but distributed among several components on the bioautoagram; besides, it was not easy to isolate each component of the phytoalexins. Therefore, furanoterpenoid phytoalexins were used or analyzed as a mixture of the components in this study. The taro strain was more sensitive to furanoterpenoid phytoalexins than the sweet potato strain. The result agreed with our previous observation. ${ }^{12)}$ Differential toxicity was also observed with umbelliferone in this study; the taro strain was also more sensitive to umbelliferone than was the sweet potato strain. Moreover, we found a difference in the mode of action of furanoterpenoid phytoalexins and umbelliferone. Furanoterpenoid phytoalexins inhibited germination and germ tube growth similarly, while umbelliferone inhibited only germ tube growth of the taro strain but not germination of either strain at the concentrations tested.

Next, we investigated the accumulation of furanoterpenoid phytoalexins and umbelliferone in infected tissues, focusing on the very early stages of infection (Figs. 3 and 4). Umbelliferone accumulated earlier than furanoterpenoid phytoalexins in tissue infected by either the sweet potato or taro strains, as reported previously. ${ }^{13,14)}$ The content of umbelliferone increased similarly in both cases in the early stage. After $24 \mathrm{hr}$, however, its content in the taro-strain-infected disks started to decrease, while it did not in the sweet potatostrain-infected disks. The decrease of umbelliferone in the taro-strain-infected disks was likely caused by degradation by fungi or the tissues themselves. In the sweet potato-straininfected disks, production of umbelliferone might balance the degradation.

Notable differences were observed in the accumulation of furanoterpenoid phytoalexins between the tissues infected by the sweet potato and taro strains. Furanoterpenoid phytoalexins content in the taro-strain-infected disks began to increase $12 \mathrm{hr}$ after inoculation, which was earlier than in the sweet potatostrain-infected tissues. The plateau of furanoterpenoid phytoalexins content after $24 \mathrm{hr}$ of incubation in the taro-strain-infected disks suggested the cessation of fungal invasion and lack of degradation of furanoterpenoid phytoalexins in the tissues. On the other hand, the amount of furanoterpenoid phytoalexins content started to increase in the sweet potatostrain-infected disks at $18 \mathrm{hr}$ and continued to increase up to the end of incubation $(48 \mathrm{hr})$. The continuous increase of furanoterpenoid phytoalexins in the sweet potato-straininfected disks suggested continuous fungal in- 
vasion into inner tissues. Such a difference in phytoalexin induction between compatible and incompatible interactions indicated that the initial recognition for host-parasite specificity must occur in advance of the production of phytoalexin. ${ }^{22 \sim 24)}$ We have proposed that the initial recognition mechanism for host-parasite specificity between sweet potato root and $C$. fimbriata involves spore agglutination factor(s) in the host and spore agglutination-inhibitory protein(s) on germinated spores. ${ }^{8,10,11,25,26)}$ The earlier induction of phytoalexin in incompatible host-parasite interaction than in the compatible interaction has also been reported in other systems. ${ }^{27,28)}$

From the results mentioned above, we speculate that the interactions between $C$. fimbriata and stress metabolites such as furanoterpenoid phytoalexins and umbelliferone in the infected sweet potato root tissues occur as follows: inoculated spores of both the sweet potato and taro strains germinate and germ tube growth occurs without any inhibition in early stage after inoculation because the tissues do not contain appreciable amounts of stress metabolites. Indeed, no significant difference was observed in the growths of the two strains on sweet potato root tissues in early stages after inoculation (Yasuda and Kojima, unpublished result). During this early period, the initial recognition for host-parasite specificity presumably takes place through interactions between spore agglutination factor(s) in the host and spore agglutination-inhibitory protein(s) on germinating spores. Results of the recognition determine the mode of production of the stress metabolites, which takes place subsequently in the infected tissues. After $3 \mathrm{hr}$, umbelliferone starts to accumulate similarly in tissues infected both by the sweet potato and taro strains. Umbelliferone inhibits germ tube growth of the taro strain more strongly than the sweet potato strain. In the meanwhile, furanoterpenoid phytoalexins begin to accumulate in the taro-strain-infected tissues, and they are more toxic to the taro strain than the sweet potato strain. As a result, the taro strain is eventually prevented from growing on sweet potato roots. In contrast, accumulation of furanoterpenoid phytoalexins are delayed in the sweet potato-strain-infected tissue, and in addition, the sweet potato strain is rather insensitive to furanoterpenoid phytoalexins. Consequently, the sweet potato strain can invade into inner tissues. The contents of furanoterpenoid phytoalexins and umbelliferone at sites where fungi and host tissues contact each other must be much higher than those reported in Figs. 3 and 4, and high enough to affect the growth of fungi since they are not distributed evenly but localized. Thus, furanoterpenoid phytoalexins and umbelliferone seem to be.involved directly in differential growth of the sweet potato and taro strains on sweet potato root tissues.

Acknowledgments. The authors are grateful to Dr. I. Uritani and Dr. S. C. Huber for helpful advice. We also thank to Dr. T. Kondo for his advice on the measurement of umbelliferone by a fluorometer and to Mr. Y. Hibino for his advice on statistical analysis of the data. This work was supported in part by a research grant from the Ishida Foundation (Nagoya).

\section{REFERENCES}

1) Y. Kono and J. M. Daly, Bioor. Chem., 8, 391 (1979).

2) V. Macko, K. Goodfriend, T. Wachs, J. A. Renwick, W. Acklin and D. Arigoni, Experientia, 37, 923 (1981).

3) S. Nishimura and K. Kohmoto, Ann. Rev. Phytopathol., 21, 87 (1983).

4) M. R. Pope, L. M. Ciuffetti, H. W. Knoche, D. McCrery, J. M. Daly and L. D. Dunkle, Biochemistry, 22, 3502 (1983).

5) N. T. Keen and M. Legrand, Physiol. Plant Pathol., 17, 175 (1980).

6) N. Doke, N. A. Garas and J. Kuć, Phisiol. Plant Pathol., 15, 127 (1979).

7) R. Barak, Y. Elad, D. Mirelman and I. Chet, Phytopathol., 75, 458 (1985).

8) K. Kawakita and M. Kojima, Plant and Cell Physiol., 24, 41 (1983).

9) K. H. Kogel, S. E. Rogozinsk, H. J. Reisenner and N. Shorn, Plant Physiol., 76, 924 (1984).

10) M. Kojima and I. Uritani, Plant and Cell Physiol., 19, 91 (1978)

11) M. Kojima, K. Kawakita and I. Uritani, Plant Physiol., 69, 474 (1982).

12) M. Kojima and I. Uritani, Physiol. Plant Pathol., 8, 97 (1976).

13) H. Hyodo, I. Uritani and S. Akai, Phytopath. Z., 65, 
332 (1969).

14) T. Minamikawa, T. Akazawa and I. Uritani, Plant Physiol., 38, 493 (1963).

15) J. A. Schneider, J. Lee, Y. Yana, K. Nakanishi, K. Oba and I. Uritani, Phytochemistry, 23, 759 (1984).

16) M. Hiura, Rep. Gif. Agr. Coll., 50, 1 (1943).

17) N. Kubota and T. Matsuura, J. Chem. Soc. Jpn., 74, 248 (1953).

18) N. Kato, H. Imazeki, N. Nakashima and I. Uritani, Tetrahedron Lett., 13, 843 (1971).

19) D. T. C. Yang, B. J. Wilson and T. M. Harris, Phytochemistry., 10, 1653 (1971).

20) I. Oguni and I. Uritani, Plant Physiol., 53, 649 (1974).

21) I. Uritani and Hoshiya, J. Agric. Chem. Soc. Jpn., 27, 161 (1953).
22) J. M. Daly, Ann. Rev. Phytopathol., 22, 273 (1984).

23) J. Kuć and J. S. Rush, Arch. Biochem. Biophys., 236, 455 (1985).

24) N. I. Vasyukova, M. S. Sabirdina, L. I. Chalova, O. L. Oazeretskovskaya, E. I. Vyskrebentseva, I. L. Semenov and N. D. Korolev, Fiziologiya Rastenii, 30, 1033 (1983).

25) K. Kawakita and M. Kojima, Agric. Biol. Chem., 48, 3063 (1984).

26) K. Kawakita and M. Kojima, Agric. Biol. Chem., 49, 2119 (1985).

27) J. A. Bailey and B. J. Deverall, Physiol. Plant Pathol., 1, 435 (1971).

28) J. L. Varns, W. W. Currier and J. Kuć, Phytopathol., 61, 968 (1971). 